\title{
THE INTERNATIONAL FINANCE INDEX@ AND ITS DERIVATIVES
}

\author{
Dariusz Wójcik \\ Oxford University Centre for the Environment \\ Working Papers in Employment, Work and Finance: WPG 07-12
}

July 2007

\begin{abstract}
The paper introduces three measures of the international financial sector and presents the ranking of countries based on these measures. The International Finance Index measures the absolute size, the International Finance Location Quotient measures the level of development, and the International Finance Diversity Index captures the degree of diversity and specialisation of a country's international financial services sector. Empirical analysis is conducted for 41 countries using the data from the BIS, the WFE, the IMF, and stock exchanges on cross-border loans and deposits, international debt securities, cross-listed stocks, as well as foreign exchange and OTC derivatives. The analysis confirms the leading position of the UK in international finance, and a relatively weak position of Japan. The paper also discusses the applicability of the International Finance Index and its derivatives in academic and policy research concerned with international financial development, and competition between financial centres.
\end{abstract}

Keywords: international finance, financial services, financial development, indices, loans, debt securities, stocks, foreign exchange, derivatives, financial centres

JEL codes: G15, N20, O16

Postal address: St. Peter's College, New Inn Hall Street, Oxford OX1 2DL, UK Email: dariusz.wojcik@spc.ox.ac.uk

Acknowledgement: I would like to thank Denis Petre and Sebastian Goerlich from the Bank for International Settlements for their invaluable help with the data.

(C) The material presented in this paper is copyright of Oxford University 


\section{Introduction}

The objective of this paper is to introduce the International Finance Index (IFI), which allows a comparative analysis of the international financial services sector based in different countries. The size of the international financial services sector is calculated one the basis of the stocks and flows of international financial transactions in the following major markets: bank loans and deposists, debt securities, stocks, foreign exchange, and over-the-counter derivatives. The IFI draws on a range of official, publicly available secondary data sources including international organisations such as the BIS and the IMF, as well as the central banks and financial authorities of individual countries. It is based on the most up-to-date data available in the middle of 2007 and covers 41 countries, including major emerging economies. Based on the same data the paper also proposes the International Finance Location Quotient (IFLQ), and the International Finance Diversity Index (IFDI), which can be considered as derivatives of the IFI, measuring the specialisation of a country's economy in international financial services, and the diversity of a country's international financial services sector respectively.

The backdrop to this paper is the high and growing significance of the international financial services sector in the world economy. First, the sector involves a high level of skills and forms an integral part of the knowledge-based economy. Second, its contribution to the GDP of advanced economies is increasing. Third, it is one of the most globalised and globalising sectors. As international financial services firms are the leading users of advanced Information and Communication Technology, their locational choices are broadening, making the map of the international financial services sector important and exciting to watch. In this context, it is not surprising to see an increasing popularity of research and policy reports evaluating the competitive position of international financial centres; Internet abounding with websites reflecting cities' and regions' aspirations to achieve or sustain the status of international financial centres; and burgeoning academic literature on the topic. ${ }^{1}$

There is, however, a gap commonly found in publications on international financial centres and international finance in general. What is lacking is a simple device measuring the size of financial centres around the world. By proposing a ranking of countries based on the size of their international financial services sector, this paper hopes to contribute to research on international finance. Given that international financial services (in contrast to domestic services) are typically concentrated in the main financial centre of a country, the IFI should also be useful in the study of financial centres.

In the next section the methods and data used to obtain the IFI, the IFLQ and the IFDI are presented, before analysing the results i.e. the values of the indices. The final section discusses some further factors to be considered in the future use and development of the proposed indices.

\footnotetext{
${ }^{1}$ See e.g. the special issue of Growth and Change (2007) European Financial Geographies. Vol. 38 (2)
} 


\section{Data and methodology}

The IFI is intended to capture the size of the international financial services sector. Four major building blocks of the sector are covered: external bank loans and deposits (L\&D), international debt securities (DSEC), trading of cross-listed stocks (STOCK), foreign exchange trading, and over-the-counter trading of foreign exchange and interest rate based derivatives (FX\&OTCD). The last two components are treated as one part of international finance, as they are very closely related to each other, and their geographies are very similar. The data on L\&D and DSEC represent the amounts outstanding of these assets. As such the IFI is composed of both stocks and flows of international finance covering all major types of international financial activities.

Data on L\&D, DSEC, and FX\&OTCD come from the Bank for International Settlements (BIS), while data on STOCK come from the World Federation of Exchanges (WFE). The sample of 41 countries covered in the paper was arrived at through the following stages. To start with, it includes 29 countries, for which BIS and WFE data were available for each of the five (four after aggregation of FX and OTCD) considered segments of international finance. Second, the missing FX and OTCD figures for the Bahamas, Bermuda, the Cayman Islands, and the Netherlands Antilles were set to 0 , which is a safe assumption given the offshore character of these financial centres. Third, the missing OTCD figures for Argentina and Mainland China were set as equal to their FX figures, which is justified considering that countries' OTCD figures are typically very similar to their FX figures. In addition, the level of FX activities in Argentina and Mainland China is minimal, and so their OTCD estimates have hardly any effect on the IFI. Third, data on L\&D for Argentina, Mainland China, Malaysia, Poland, Russia, South Africa, and Thailand, unavailable in the BIS database, were taken from the International Financial Statistics (IFS) of the International Monetary Fund (IMF). Fourth, data on STOCK for the Bahamas, the Cayman Islands, the Netherlands Antilles, Russia, and Singapore, unavailable from the WFE, were taken from the websites of individual stock exchanges.

The sample of 41 countries includes all major economies of the world, accounting for approximately $91 \%$ of the world's GDP, covering all major locations of international financial services. Bermuda, the Cayman Islands, Hong Kong SAR, and the Netherlands Antilles do not have a country status, but because data on them are available and they represent important financial centres, they are included in the paper alongside sovereign countries. While keeping in mind these exceptions, the geographical entities covered in the paper are referred to simply as countries.

The paper is based on the most up-to-date data available in the public domain in the middle of 2007, which does not mean, however, that the data stand for the end of June 2007. Data availability differs between different components of international finance. For L\&D the data stand for the outstanding value of external loans and deposits at the end of 2006; for DSEC - the outstanding value of international debt securities at the end of the first quarter of 2007; for STOCK - the value of trading in foreign stocks in the first five months of 2007; for FX\&OTCD - the average daily value of trading in foreign exchange and OTC traded foreign exchange- and interest rate-based derivatives in April 2004. The data on FX\&OTCD is based on a triennial survey of the BIS, and the figures for 2007 will be available in September 2007. 
Regarding the currency in which the data used in the paper are expressed, the core data sourced from the BIS and the WFE were used as published by these institutions in USD current prices. The supplementary data on L\&D and STOCK sourced from the IFS and stock exchange websites were translated from domestic currencies into USD, using foreign exchange rates as at the end of 2006 (for L\&D), and the average of the five end of month foreign exchange rates for the period January-May 2007 (for STOCK). As a result the data are fully comparable within each of the four segments of the international financial sector.

What makes the analysed financial stocks and flows international and how are they assigned to countries? The answer is based on the BIS methodology as well as certain conventions applied by the author. Starting with L\&D, the data represent the outstanding values of banks' loans granted to and assets deposited with entities located in other countries. The data come from the BIS locational, not the consolidated, banking statistics, and so in the case of bank branches or subsidiaries, loans and deposits are recorded in the country where these entities reside, not the country of their headquarters.

DSEC cover long-term bonds, notes, and short-term money market instruments issued in international markets. The definition of international securities (as opposed to domestic securities) is based on three features: the location of the transaction, the currency of issuance, and the residence of the issuer. "International issues comprise all foreign currency issues by residents and non-residents in a given country and all domestic currency issues launched in the domestic market by non-residents. In addition, domestic currency issues launched in the domestic market by residents are also considered as international issues if they are specifically targeted at non-resident investors." 2 The data involves amounts outstanding of the international debt securities by the country of residence (not the nationality) of the immediate (not the ultimate) issuer of the securities. For example, if a London branch of GE Capital issues international bonds in order to finance General Electric, they are counted as international financial transaction in the UK, even though the General Electric as the ultimate issuer, and the headquarters of the GE Capital are located in the USA. To be sure, in order to capture the geography of the international debt securities markets, it would be useful to supplement the data on issuance with those on underwriting activities and the secondary markets trading debt securities. Such data are however not publicly available.

Data on STOCK refer to the value of trading in foreign equities, and are assigned to the location of the stock exchange on which these equities are traded. 'Foreign equities' are equities issued by companies headquartered in a country different than the country of the stock exchange. Two modifications of this rule are to be noted. First, companies headquartered in Mainland China are considered as foreign in Hong Kong. Second, the notion of cross-listing is complicated by international mergers of stock exchanges. The convention applied here is to assign the trading in foreign stocks traded on the Euronext to France, and those traded on the OMX to Sweden. 'Foreign stocks' are defined as those issued by companies headquartered outside of France, Belgium, Netherlands, and Portugal, and outside of Sweden, Denmark, Finland, Iceland, Estonia, Latvia, and Lithuania, respectively. To be sure the trading in cross-

\footnotetext{
${ }^{2}$ BIS Paper 14 (2003) p.13-14, available on www.bis.org.
} 
listed stocks is far from a perfect measure of international stock market activity. It could be supplemented with data on the primary markets including international equity issuance and underwriting, as well as those on foreign trading in domestic equities (e.g. foreign trading in British equities listed on the London Stock Exchange). Public availability of such data is however very limited.

OTCD include forwards, options, swaps and other derivative instruments based on foreign exchange and interest rates. As FX\&OTCD transactions involve currencies and interest rates of different countries, they are all considered international, even though they are partly conducted between local dealers. The FX\&OTCD figures are assigned to the location of the sales desk of a trade, not the location of the headquarters of the institution the sales desk is a part of. ${ }^{3}$

\section{The Indices}

The formula applied for calculating the IFI in country $i$ is the following.

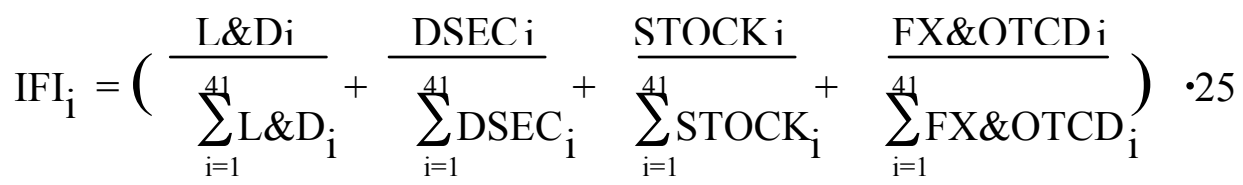

The IFI thus represents the average of a country's percentage shares in the four groups of international financial activities. For each group the sum of the flows or stocks for all 41 countries is assumed as $25 \%$ of the entire international financial services sector. In other words, each of the four segments of the international financial sector is given an equal weight in the IFI. If the entire international financial sector was concentrated in one country, this country would have an IFI of 100.

The IFI is used to calculate a location quotient, relating a country's share in international financial services to its share in GDP.

$$
\mathrm{IFLQ}_{i}=\frac{\mathrm{IFI}_{\mathrm{i}}}{100} \div \frac{\mathrm{GDP}_{\mathrm{i}}}{\sum_{\mathrm{i}=1}^{4} \mathrm{GDP}_{i}}
$$

Countries with high values of the IFLQ can be considered as those with developed international financial services sector. Data on GDP is for 2006, expressed in current prices in USD, and comes from the IMF's World Economic Outlook Database (April 2007). It includes IMF's estimates where actual data were not available. Figures for Bermuda, the Cayman Islands, and the Netherlands Antilles come from their official statistical offices.

Finally, the formula applied for calculating the IFDI is a version of the Simpson's diversity index. ${ }^{4}$

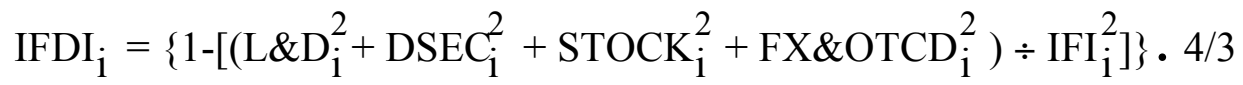

\footnotetext{
${ }^{3}$ For details see BIS (2005) Triennial Survey, available on www.bis.org.

${ }^{4}$ For details see e.g. Colinvaux, P.A. (1973) Introduction to Ecology. Wiley.
} 
The more diverse a country's international financial sector, the higher the value of the IFDI. If a country's entire international financial sector is based on only one of the four segments of the sector, the IFDI takes the value of zero. If it is spread equally across the four segments, the FDI takes the value of 1 .

\section{Results}

International financial transactions of the 41 countries analysed in this paper involve vast amounts of money. The value of outstanding external bank loans and deposits at the end of 2006 was $\$ 18,551 \mathrm{bn}$, and the value of outstanding international debt securities at the end of March 2007 \$18,504bn. The value of trading in cross-listed stocks in the first five months of 2007 equalled \$4,253bn, and the average daily value of trading in foreign exchange and OTC derivatives in April 2004 reached \$5,449bn.

Table 1 presents the ranking of countries according to the IFI, the components of the IFI i.e. countries' shares in each of the four major international financial activities, as well as the values of the IFLQ and the IFDI. The United Kingdom leads the ranking, followed by the USA. Together they account for more than $50 \%$ of the possible IFI points, which means that the majority of the international financial transactions are conducted in the UK or the USA. Germany and France with the IFI of 7.10 and 4.62 occupy the third and the fourth position respectively. Places five to seven are taken by Hong Kong, the Netherlands, and the Cayman Islands, with very similar IFI values. Japan comes only eighth, and is followed closely by Switzerland. The last countries with the IFI above 2 are Singapore in the tenth, and Italy in the eleventh position. It is also worthwhile noting the high ranks of Ireland and Luxembourg in the thirteenth and fourteenth place respectively.

Figure 1 depicts the IFI and its composition on the map of the world, further highlighting the unequal distribution of the international financial services sector. The total IFI of the European Union exceeds 44, which is more than double the figure for the USA. The weight of the EU in international finance also translates into the dominance of the European time zone (European countries, including Russia and Turkey, plus South Africa), accounting for nearly $62 \%$ of international finance, compared to the share of approx. $27 \%$ for the Americas, and only approx. $11 \%$ for the Asia-Pacific. The map also highlights the differences between countries in terms of the composition of their IFI scores. The EU as a whole has a very balanced structure of the international financial services sector. The Asian countries lack a developed international debt securities sector. The American offshore centres of the Bahamas, Bermuda, the Cayman Islands, and the Netherlands Antilles specialise in external loans and deposits or international debt securities. Trading of cross-listed stocks is absolutely dominated by the UK, the USA, and Hong Kong - one centre in each of the three time zones.

To further analyse the development of the international financial services sector by country, we consider the IFLQ in conjunction with the IFDI. Figure 2 proposes a simple matrix dividing countries into three groups depending on the combination of the relative size (IFLQ) and diversity (IFDI) of their international financial sector. Countries with high IFLQ and high IFDI have developed and diversified international financial sectors. Countries with high IFLQ and low IFDI have developed specialised 
international financial sectors. Countries with low IFLQ have underdeveloped international financial sectors. The cut-off points between different categories can be only arbitrary, and here they were assumed as the median values of the IFLQ and the IFDI. The resulting classification is presented in figure 2.

The UK, Sweden and Germany appear as leading countries with developed and diversified international financial sectors, but the group also includes France, Austria, Singapore and the USA. Developed specialised international financial sectors can be attributed to the Bahamas, Bermuda, the Cayman Islands, and the Netherlands Antilles, but also to Ireland, Luxembourg, Belgium, and Hong Kong. The Netherlands, Denmark, Australia, and Switzerland appear on the border between the first and the second group. The category of countries with underdeveloped international financial sectors consists mostly of emerging economies, but it also includes the 'long-emerged' economies of Canada, Finland, Greece, Italy, Portugal, and most importantly Japan.

\section{Concluding remarks}

This paper introduced the International Finance Index, and analysed the ranking of 41 countries based on this index. The calculation of the IFI involves publicly available, reliable, and regularly updated data covering the major segments of the international financial sector. The interpretation of the IFI is simple, as it represents a country's weighted share in international finance. In addition, the derivatives of the IFI, the International Finance Location Quotient and the International Finance Diversity Index offer further insight into the development and structure of international finance. In particular, they allow identification of countries with developed and diversified, developed specialised, and underdeveloped international financial sectors.

There are many potential applications of the IFI and its derivatives. First, they can be used as a simple but effective device to monitor the global map of international finance. Time-series data, for example, would allow us to find out whether emerging economies expand their international financial sectors in the future, and whether Japan, Canada or Italy continue to 'punch below their economic weight'. Second, the IFI and derivatives can be used in academic studies evaluating factors that affect the development of the international financial services sector, for example by relating the IFLQ to variables capturing the openness or the quality of regulation by country. Third, the indices can be used in academic and policy research focused on the competition between international financial centres. Obviously, the IFI is more a reflection of the past competitiveness of a location than an indicator of the future competitiveness. Nevertheless, the past and the size matter considering a strong degree of path dependence and high intensity of scale economies prevailing in international finance. ${ }^{5}$

\footnotetext{
${ }^{5}$ For a discussion on path dependence and scale economies see e.g. Porteous, D. (1999), 'The Development of Financial Centres: Location, Information Externalities and Path Dependence', in R. Martin (ed.), Money and the Space Economy, Chichester: J Wiley \& Sons, 95-114. For an example of the author's recent work on finance see Clark, G.L., and Wójcik, D. (2007) The Geography of Finance: Corporate Governance in the Global Marketplace. Oxford University Press.
} 
Table 1. The International Finance Index, its components and derivatives

This table presents the ranking of countries based on the IFI. The components of the IFI i.e. L\&D, DSEC, STOCK, FX\&OTCD represent the percentage shares of a country in a given international financial activity. The IFI is an equally weighted average of these shares. The IFLQ is a location quotient relating the IFI of a country to its share in the GDP. The IFDI measures the diversity of a country's international financial sector. The formulae for calculating the IFI, IFLQ, and IFDI are presented on page 5. Abbreviations for the components of the IFI are explained on page 3. Source: Author's calculations based on data from the BIS, WFE, IMF, central banks and stock exchanges

\begin{tabular}{|c|c|c|c|c|c|c|c|c|}
\hline Rank & Country & IFI & L\&D & \multicolumn{3}{|c|}{ DSEC STOCK FX\&OTCD } & IFLQ & IFDI \\
\hline 1 & United Kingdom & 30.25 & 21.21 & 14.59 & 49.79 & 35.40 & 5.56 & 0.93 \\
\hline 2 & United States & 21.30 & 12.34 & 22.75 & 30.65 & 19.45 & 0.70 & 0.97 \\
\hline 3 & Germany & 7.10 & 10.11 & 10.56 & 3.24 & 4.50 & 1.07 & 0.93 \\
\hline 4 & France & 4.62 & 6.71 & 6.51 & 0.31 & 4.94 & 0.90 & 0.90 \\
\hline 5 & Hong Kong & 3.59 & 2.34 & 0.27 & 8.38 & 3.38 & 8.27 & 0.77 \\
\hline 6 & Netherlands & 3.39 & 3.91 & 7.61 & 0.00 & 2.02 & 2.23 & 0.77 \\
\hline 7 & Cayman Islands & 3.35 & 8.12 & 5.29 & 0.00 & 0.00 & 731.13 & 0.64 \\
\hline 8 & Japan & 2.82 & 3.42 & 0.82 & 0.02 & 7.05 & 0.28 & 0.69 \\
\hline 9 & Switzerland & 2.60 & 5.62 & 0.13 & 1.85 & 2.81 & 3.01 & 0.81 \\
\hline 10 & Singapore & 2.19 & 3.08 & 0.27 & 1.28 & 4.13 & 7.23 & 0.84 \\
\hline 11 & Italy & 2.17 & 1.95 & 4.26 & 1.12 & 1.34 & 0.51 & 0.89 \\
\hline 12 & Spain & 1.90 & 1.46 & 5.29 & 0.18 & 0.66 & 0.68 & 0.63 \\
\hline 13 & Ireland & 1.82 & 2.28 & 4.59 & 0.00 & 0.40 & 3.57 & 0.67 \\
\hline 14 & Luxembourg & 1.51 & 3.36 & 2.10 & 0.00 & 0.61 & 16.28 & 0.75 \\
\hline 15 & Australia & 1.50 & 0.32 & 2.36 & 0.50 & 2.83 & 0.87 & 0.82 \\
\hline 16 & Belgium & 1.32 & 3.23 & 0.87 & 0.00 & 1.19 & 1.47 & 0.73 \\
\hline 17 & Canada & 1.29 & 1.06 & 1.99 & 0.16 & 1.96 & 0.44 & 0.89 \\
\hline 18 & Sweden & 0.97 & 0.87 & 1.10 & 0.78 & 1.16 & 1.10 & 0.99 \\
\hline 19 & Austria & 0.92 & 1.23 & 1.71 & 0.07 & 0.66 & 1.24 & 0.85 \\
\hline 20 & Denmark & 0.72 & 0.75 & 0.57 & 0.00 & 1.56 & 1.14 & 0.80 \\
\hline 21 & Norway & 0.50 & 0.19 & 0.65 & 0.60 & 0.57 & 0.65 & 0.96 \\
\hline 22 & Bahamas & 0.45 & 1.76 & 0.03 & 0.00 & 0.00 & 31.37 & 0.05 \\
\hline 23 & China Mainland & 0.40 & 1.47 & 0.09 & 0.00 & 0.04 & 0.07 & 0.20 \\
\hline 24 & South Africa & 0.37 & 0.18 & 0.08 & 0.83 & 0.39 & 0.63 & 0.80 \\
\hline 25 & South Korea & 0.34 & 0.28 & 0.49 & 0.00 & 0.57 & 0.17 & 0.86 \\
\hline 26 & Greece & 0.33 & 0.26 & 0.83 & 0.11 & 0.13 & 0.47 & 0.74 \\
\hline 27 & Russia & 0.32 & 0.34 & 0.29 & 0.00 & 0.66 & 0.14 & 0.82 \\
\hline 28 & Finland & 0.26 & 0.41 & 0.58 & 0.00 & 0.06 & 0.54 & 0.71 \\
\hline 29 & Portugal & 0.24 & 0.45 & 0.46 & 0.00 & 0.07 & 0.55 & 0.76 \\
\hline 30 & Mexico & 0.21 & 0.06 & 0.36 & 0.04 & 0.39 & 0.11 & 0.80 \\
\hline 31 & Netherlands Antilles & 0.18 & 0.12 & 0.60 & 0.00 & 0.00 & 28.00 & 0.36 \\
\hline 32 & Taiwan, China & 0.17 & 0.31 & 0.10 & 0.02 & 0.26 & 0.21 & 0.85 \\
\hline 33 & Brazil & 0.16 & 0.10 & 0.43 & 0.02 & 0.09 & 0.07 & 0.68 \\
\hline 34 & Poland & 0.15 & 0.16 & 0.20 & 0.03 & 0.22 & 0.19 & 0.92 \\
\hline 35 & Turkey & 0.12 & 0.17 & 0.24 & 0.00 & 0.09 & 0.14 & 0.83 \\
\hline 36 & India & 0.11 & 0.13 & 0.11 & 0.00 & 0.20 & 0.05 & 0.86 \\
\hline 37 & Argentina & 0.10 & 0.02 & 0.34 & 0.01 & 0.04 & 0.21 & 0.40 \\
\hline 38 & Thailand & 0.07 & 0.14 & 0.06 & 0.00 & 0.09 & 0.15 & 0.84 \\
\hline 39 & Malaysia & 0.07 & 0.08 & 0.14 & 0.02 & 0.06 & 0.21 & 0.87 \\
\hline 40 & Bermuda & 0.06 & 0.02 & 0.22 & 0.00 & 0.00 & 5.80 & 0.21 \\
\hline 41 & Chile & 0.04 & 0.02 & 0.08 & 0.00 & 0.06 & 0.11 & 0.78 \\
\hline & TOTAL & 100.00 & 100.00 & 100.00 & 100.00 & 100.00 & NA & $\mathrm{NA}$ \\
\hline
\end{tabular}


Figure 1. Global finance according to the International Finance Index
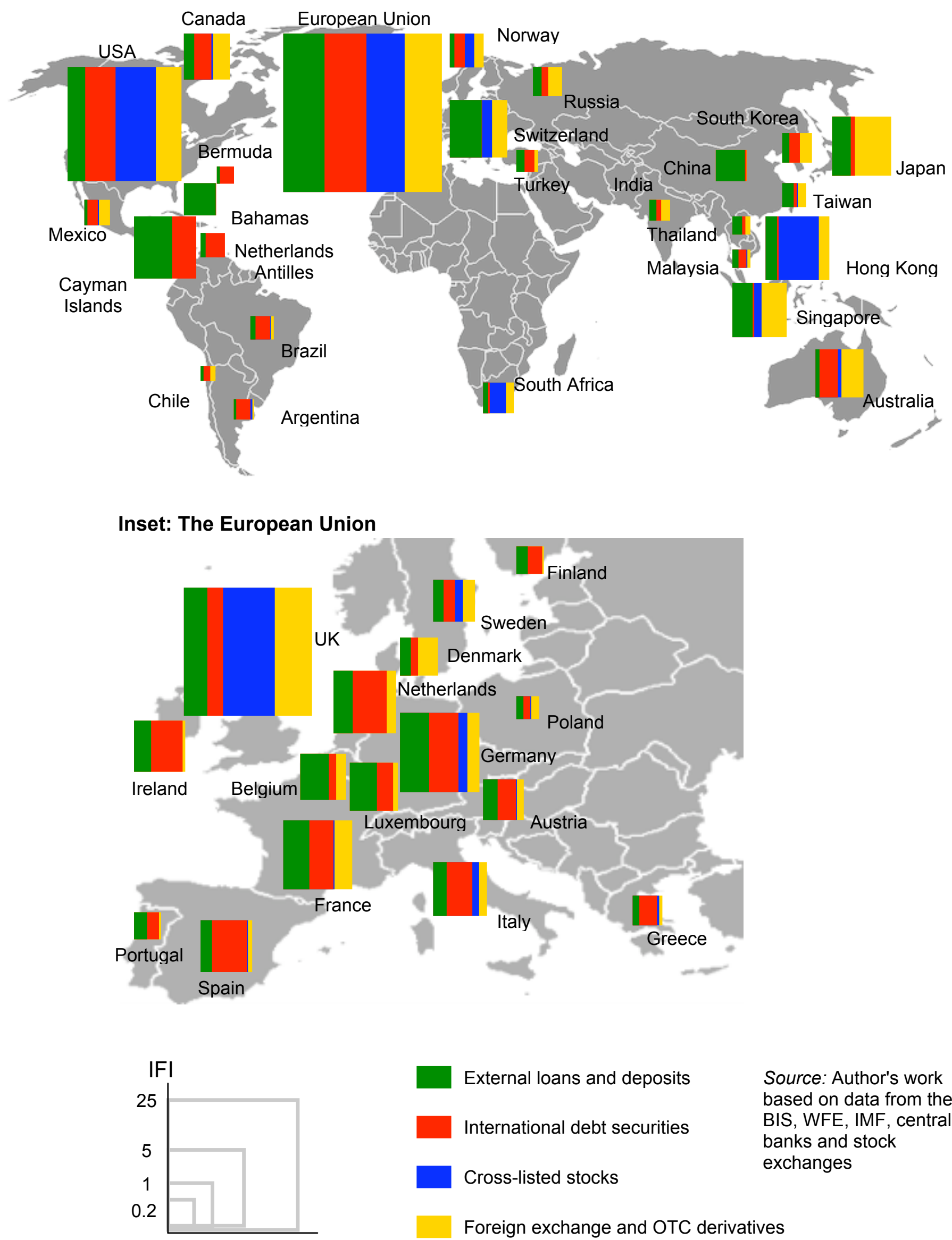

External loans and deposits

International debt securities

Cross-listed stocks

Foreign exchange and OTC derivatives 
Figure 2. The International Finance Location Quotient and the International Finance Diversity Index

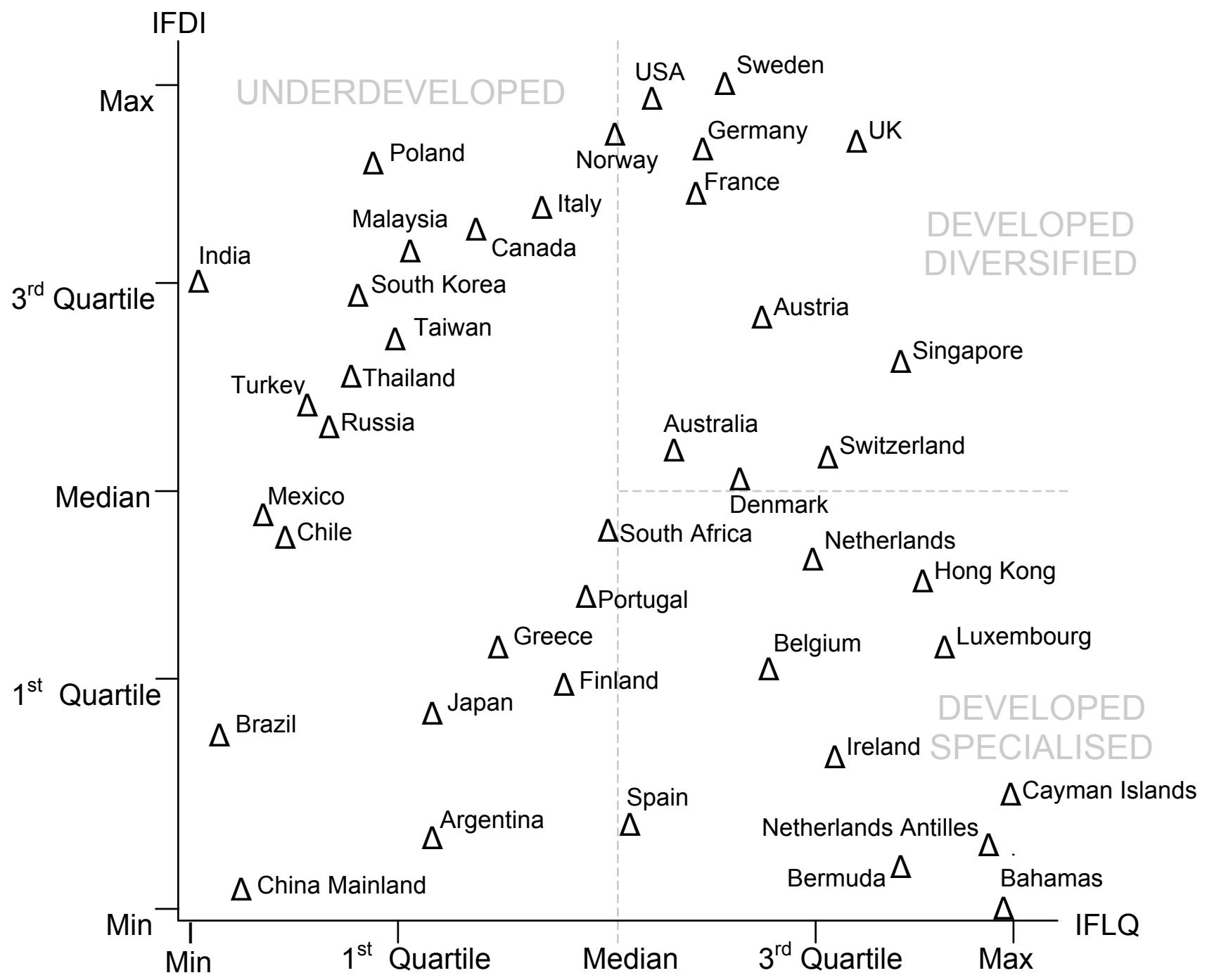

Note: Axes $\mathrm{X}$ and $\mathrm{Y}$ are scaled according to the ranking of countries based on the IFLQ and the IFDI respectively.

Source: Author's work based on data from the BIS, WFE, IMF, central banks and stock exchanges 